\title{
The Westminster Parliament's Formal Sovereignty in Britain and Europe from a Historical Perspective*
}

JOHN W.F. ALLISON

Introduction

Thank you, Professor Mii ig and ReConFort, for inviting me to give this lecture and for your excellent hospitality, which has made my visit to the Carl Friedrich von Siemens Foundation here in Munich a great pleasure.

This lecture might just as well have been entitled The Westminster Parliament's Formal and Substantive Sovereignty, but the extension would have been long and inelegant, and, as it stands and as will become apparent, the title reflects the exercise of sovereignty' that resulted in the United Kingdom's Brexit referendum on 3 June of this year. On the Brexit referendum, I should add that I am pleased at least to come from Cambridge and to be close to London - two cities that strongly supported the Remain campaign!

Advocacy of Brexit was expressed with the popular slogan "Take back control", which has two main dimensions - "control of borders" on the one hand, and "control of laws" on the other. The second of these raises the issue of Parliament's sovereignty, which has held the status of the ultimate legal and political principle, the Grundnorm, or the basic rule of recognition, in much positivist legal thinking about the British legal systemz. "Control of borders" was of far greater political significance, but "Control of laws" was also significant both in its general appeal to most Brexit leaders (not Nigel Parage, but Boris Johnson, Liam Fox and Michael Gove for example) and to those from the intelligentsia who supported Brexit, and as a veneer of respectability for the less seemly side of "Control of borders" relating to immigration.

Now, my college in Cambridge is Queens' College, and, in the lead-up to the Brexit referendum, two of our former students who are now Members of Parliament (MPs) - on opposite sides - came to debate the issues. The one alumnus is Lahour Party MP Stephen Kinnock, the son of former Leader of the Opposition and 


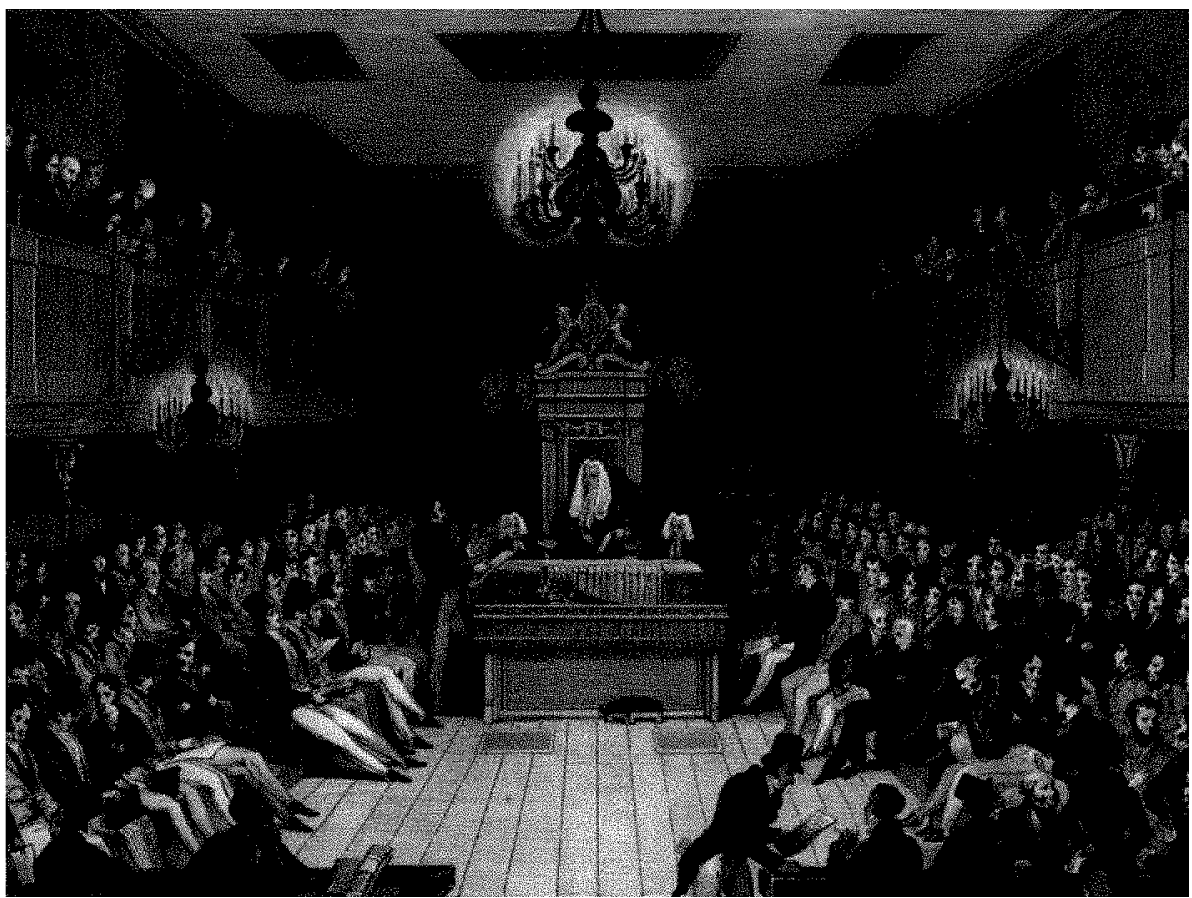

The Speakerpresides o er debates in the House of Commons, 1834 print

former European Commissioner Neil Kinnock (and Stephen is married to the former Prime Minister of Denmark Helle Thorning-Schmidt), The other alumna is Conservative Party MP Suella Fernandes, who was elected in the General Election last year (015), and who was therefore worrying that almost her fust main move as an MP was to oppose her Prime Minister and Government by campaigning for Brexit, What were striking in their debate on the issues were two contrasting and competing conceptions of the Westminster Parliament's sovereignty (as it was in other debates on the Brexit referendum), Suella Fernandes, who had studied law at university, presented a legal conception, one that had been encroached upon formally through the effective asser- tion of the supremacy of Community law by the ECJ (as they were then called) and thereafter through acceptance of that supremacy by the British courts, defmitively by the House of Lords (as it was then called) in the Factortame litigation ${ }^{3}$, resulting in disapplication of provisions of the Merchant Shipping Act 1988 enacted by Parliament, Stephen Kinnock, in contrast, presented a substantive political conception of the reality of what Parliament can and cannot do, He argued that EU membership actually enhances Parliament's sovereignty by enabling it to do much more through the EU than it would otherwise be able to do, $\mathrm{He}$ argued further, as I remember, that Brexit would make little difference to the practical constraints on Parliament's sovereign- 
ty, because international trade deals by the UK with the EU (as with other state entities or states elsewhere) would thereafter be conditioned on compliance with such constraints (Prime Minister Cameron went so far as to say that Parliament's sovereignty in the minds of the Brexit campaigners was an illusion).

Explaining the background and relative significance of the contrasting conceptions of the Westminster Parliament's sovereignty, exemplified in that Brexit debate in Queens' College, is the subject of this lecture. It has four main parts. First, I will seek to explain this dichotomy of formal legal and substantive political conceptions of Parliament's sovereignty as a doctrinal product of Albert Venn Dicey's foundational multi-edition textbook The Law of the Constitution, first published in 18854. Secondly, I will suggest the historical significance of Dicey's exposition, relative to prominent earlier constitutional writings and in relation to the theme of juridification in the ReConFort project. Thirdly, I will present various prominent manifestations of the formal legal conception of the Westminster Parliament's sovereignty, and of the concurrence or simultaneous role of various substantive conceptions alongside the formal. Fourthly and finally, I will focus on the real and/or apparent transfer of sovereign powers to the EU institutions as the backdrop to Brexit and its implications.

Let me return, first, to the Brexit debate in Queens' College. My own, personal, problem is that, in context, on the implications of Brexit for Parliament's sovereignty, I agreed with Stephen Kinnock but I had supervised/tutored Suella Fernandes in Constitutional Law at Queens' College. What had I taught her and where had I gone wrong...? Suella had been taught, as the usual starting point, Dicey's account of parliamentary sovereignty, but, in retrospect, we in English academia may well have paid too much attention to his one pillar of the British Constitution - the rule of law - the various formal and substantive conceptions of the rule oflaw5, atthe expense ofhis other pillar- the sovereignty of Parliament.

\section{Dicey's Dichotomy of \\ Substantive Formal and} Sovereignty Conceptions of Parliament's

In his treatment of Parliament's sovereignty, Dicey was concerned with two observational difficulties for someone studying the English constitution ${ }^{6}$ (as he called it). The one was that Parliament was said to be sovereign, but sovereignty was at least shared with the electorate through Parliament's representative character. The other was that sovereignty was said to be unlimited, but was clearly subject to limited practicability in day-to-day politics. His answer to these observational difficulties for students studying the constitution was to distinguish between the legal sense of Parliament's sovereignty - the lack of any legal limit to law making- and the political sense in which the electorate (through the House of Commons), the House of Lords and the King were sovereign. This distinction overlapped with a second distinction. Parliament's sovereignty in its legal sense was theoretically limitless, whereas its sovereignty in its political sense was subject to various, innumerable, limits in actuality. In expounding the law of the constitution, Dicey's focus was purely on the legal con- 
ception, and it provided a basic rule - "an undoubted legal fact" (thus largely unjustined in Dicey's account) - for the courts to obey/apply any parliamentary legislative enactment whatever its content? Part of the rule reflected ${ }^{8}$ the maxim $<<$ Parliament cannot bind its successors $>>$. It required that, if a later Act of Parliament is inconsistent with an earlier Act, the later Act be taken to have repealed by implication the earlier Act to the extent of the inconsistency. Dicey's legal conception of Parliament's sovereignty was formal, even ftctitious, because it required the courts to treat Parliament's sovereignty as limitless although it was clearly limited in political actuality or practicability.

Dicey's comparative constitutional lectures were ftrst delivered and written from 1895 to 1900 , but they were lost both to the public and academia until about 1985, and they remained largely unpublished until publication of The Oxford Edition of Dicey in oi39. They now shed light on Dicey's account of Parliament's sovereignty in an important way. Contrasting the different spirits of different constitutions (such as the civil administrative spirit of French constitutionalism or the military spirit of Prussian constitutionalism of his day) he described the legal spirit of the institutions of the English constitution ${ }^{10}$. For him, that legal spirit was a love for legal forms and an acquiescence in ftctions, such as the ftction in the seventeenth century that King Charles II immediately succeeded King Charles I. That was the ftction by which $<<$ Englishmen ... contrived to forget the fall of the monarchy $>>$, with the effect that $<<$ the very memory of the Interregnum $>>$ from 1649 to 1660 (when the reigns of Charles I and Charles II were separated by the Com- monwealth of England and the Protectorate) was <<blotted out from popular tradition $>>$ ". For Dicey, the English constitution was viewed from the perspective of a people with $<<$ a legal turn of mind and a love for forms and precedents $>>$ who $<<$ imbued with legalism ... import into their political arrangements that love of precedent and acquiescence in ftctions which is proper to the law courts > $>$ z. Dicey's formal legal conception of Parliament's sovereignty' ${ }^{3}$, its longevity and influence were in accordance with that legal spirit, as was that spirit's importation into the English political arena.

\section{The Historical Significance of Dicey's Exposition of the Law of the Constitution and of Parliament's Sovereignty}

What is also clear from Dicey's comparative constitutional lectures is that he saw the English constitution as the prime example of a historical constitution, as did most of his contemporaries, exhibiting characteristics of"antiquity"," continuity", etc.'4 His conception of it as a historical constitution is consistent with his abundant historical references, in his famous work The Law of the Constitution, to the antiquity of Parliament's sovereignty and the critical importance of the formative struggles between Crown and Parliament in the seventeenth century'S.

The historical signiftcance of Dicey's exposition, however, was principally the thoroughness, authority and lasting influence of his attempt to juridify or juridicalise, even judicialise, the English historical constitution through legal doctrine in The Law of the Constitution. He put the rule of law in pride 
of place as the second pillar of the constitution. The third meaning he attributed to the rule of law (after his fust two meanings centred on legal certainty and equality before the law) was of the English constitution itself as the <<result of [the] ordinary law of the land $>>$, principally $<<$ the consequence of the rights of individuals, as defmed and enforced by the Courts $>>{ }^{\prime} 6$. Further, parliamentary sovereignty was his ftrst-stated pillar of the English constitution, but the conception with which he was concerned was a legal and theoretical conception. It was the conception of the $<<$ Unlimited legislative authority of Parliament $>>$, the lack of any limit to law making, providing the rule for the courts that they apply whatever Parliament enacts in an Act of Parliament'? It was distinct from the political conception of Parliament's sovereignty subject to external and internal limits, constraining actual political practicability' ${ }^{\prime}$.

Earlier prominent writings on the English constitution, such as those of Coke, Blackstone, De Lolme, Cox and Hearn'9, emphasised or listed all that Parliament could do in the exercise of its sovereign legislative authority. According to Edward Coke in 1644zo,

Of the power and jurisdiction of the parliament, for making of laws in proceeding by bill, it is so transcendent and absolute, as it cannot be confined either for causes or persons within any bounds. Of this court it is truly said: Si antiquitatemspectes. est etustissima. si dignitatem. esthonoratissima. sijurisdictionem. est capacissima.

In 1765 William Blackstone, after quoting Coke's passage, listed all that Parliament could do and all the matters in respect of which they could be doneZ':

[Parliament] hath sovereign and uncontrolable authority in making, confirming, enlarging, restraining, abrogating, repealing, reviving, and expounding of laws, concerning matters of all possible denominations, ecclesiastical, or temporal, civil, military, maritime, or criminal: this being the place where that absolute despotic power, which must in all governments reside somewhere, is entrusted by the constitution of these kingdoms.

These writings lack the distinction between legal and political conceptions, with the legal conception providing a rule for the courts. In 1867, according to William Hearnzz (to whom Dicey expressed his greatest indebtedness in his preface $Z^{3}$ ),

\footnotetext{
It is now universally conceded that the authority of Parliament in matters of legislation is unlimited ... [W] [Wen the meaning [of an Act of Parliament] is clear, it is the duty of the Court not to question the wisdom of the statute but to obey its commands.
}

Thus Hearn also presented parliamentary sovereignty as providing a rule for the courts, but he did not elaborate a distinction between legal and political conceptions of sovereignty, as did Dicey.

\section{Manifestations of the Fonnal Legal Conception of Parliament's Sovereignty and of the Concurrence of Substantive Conceptions}

In various ways since Dicey's The Law of the Constitution was ftrst published, the highly formal quality of the Westminster Parliament's legal sovereignty has been manifest in its exercise to the great detriment of its substantive sovereignty, and has accordingly provoked unease. 
3.1. One manifestation was in the process of decolonisation through parliamentary enactments of the Westminster Parliament conferring self-government or independence on colonies and dominions. They contributed to a much earlier, imperial, form of transnational constitutionalism in Britain and the rest of the British Commonwealth, which became the Commonwealth of Nations. In strict legal theory, Parliament retained the right to legislate for the independent dominions initially subject only to the convention that it not does so without the consent of a dominion. The Statute of Westminster 1931 removed limitations on the competence of dominion parliaments and effectively replaced the convention with the provision in section $4=$

No Act of Parliament of the United Kingdom passed after the commencement of this Act shall extend, or be deemed to extend, to a Dominion as part of the law of that Dominion unless it is expressly declared in that Act that the Dominion has requested, and consented to, the enactment thereof.

The courts still recognised, nonetheless, that Parliament's power to legislate remained unimpaired as a matter of strict law. In relation to Canada, Viscount Sankey L.C. acknowledged that it did so in the British Coal Corporation case (1935)' 4 ,

It is doubtless true that the power ofthe Imperial Parliament to pass on its own initiative any legislation that it thought fit extending to Canada remains in theory unimpaired: indeed, the Imperial Parliament could, as a matter of abstract law, repeal or disregard s. 4 of the Statute. But that is theory and has no relation to realities. In truth Canada is in enjoyment of the full scope of selfgo emment ...

Lord Denning M.R. in the Blackburn case (1971) similarly acknowledged Parliament's unimpaired power to legislate and also emphasised the consequent artiftcialityZ5,

We have all been brought up to believe that, in legal theory, one Parliament cannot bind another and that no Act is irreversible. But legal theory does not always march alongside practical reality. Take the Statute of Westminster 1931, which takes away the power of Parliament to legislate for the Dominions. Can one imagine that Parliament could or would reverse that Statute? Take the Acts which have granted independence to the Dominions and territories overseas. Can anyone imagine that Parliament could or would reverse those laws and take away their independence? Most clearly not. Freedom once given cannot be taken away. Legal theory must give way to practical politics.

The UK Parliament's legal and political conceptions of sovereignty -limitless in legal theory, but limited in practical politicswere thus a source of unease and, earlier, of some instability $(<<$ a double-edged sword $>>$ according to excellent recent work) $\mathrm{Z}^{6}$. Fortunately, sovereignty was usually exercised with political restraint - a pragmatic concession to the geographical distance of Britain from its colonies and dominions and with the light touch of a $<<$ constitutional ethic ... of laissez-faire $>$ at least towards those that were self-governingZ7.

3.::, A second manifestation ofthe formal legal conception of Parliament's sovereignty at work has been the increased use of "Henry VIII clauses" through the course of the last century. They have been named after clauses in Acts of Parliament by which sweeping law-making powers were conferred upon King Henry VIII, especially in the infamous Statute of Proclamations of 1539 (31 Henry VIII, c. 8) by which the King's proclamations 
were to have the sameforce as Acts ofParliament subject to restrictions (the absence of prejudice to inheritances, liberties, goods etc.). The statute was repealed on Henry VIII's deathini547.

In this and the last century Henry VIII clauses have involved the grant of powers to the executive to legislate by executive order and thereby amend what Parliament has enactedZ ${ }^{8}$. The Human Rights Act 1998, section 10, is a well-known example in providing for fast-track ministerial amendment of parliamentary legislation to be incompatible with European Convention rights, subjectto a process of parliamentary approval provided for in schedule to the Act. Henry VIII clauses have been a particular concern of Lord Igor Judge, former Lord Chief Justice of England and Wales, as a circumvention of Parliament's substantive role and functionZ9. Although $\ll<$ when these Henry VIII clauses are introduced they will always be said to be necessary $>>$ and are the outcome of the exercise of Parliament's formal legal sovereignty, Lord Judge has portrayed them as detrimental to Parliament's actual substantive sovereignty:

Half a moment's thought will demonstrate that proliferation of clauses like these will have the inevitable consequence of yet further damaging the sovereignty of Parliament, and increasing yet further the authority of the executive over the legislature ${ }^{30}$.

On the premise of detriment to the sovereignty of Parliament, Lord Judge has coneluded that $<<$ Henry VIII clauses should be confmed to the dustbin of history $>{ }^{3}$. They are highly unlikely to be so confmed. Rather, their greatly increased and prominent use may well again be said to be necessary so as to effect the legal changes pursuant to Brexit $^{3} \mathrm{Z}$.
3.3. A third manifestation of the formal legal conception at work has been the Westminster Parliament's asymmetric devolution of governing powers to Scotland, Wales and Northern Ireland, in which express provision has been made, as in the Scotland Act 1998, for the conferral of legislative competence on the Scottish Parliament not to <<affect the power of the Parliament of the United Kingdom to make laws for Scotland $>>33$. Shortly before Tony Bair became Prime Minister, he said as much in the 1997 General Election campaign. When interviewed on the implications of the Labour Party's Scottish legislative devolution proposals in their manifesto, he stressed that sovereignty would still belong solely to the Westminster Parliament, that it <<rests with me as an English MP and that's the way it will stay $>3_{4}$. Then, maintaining that his fwe-yearpledge on tax $<<$ applies to Scotland as it does to England $>>$, he made the political blunder of comparing the tax-varying powers of the proposed Scottish Parliament to those of an English parish council (a civillocal authority in the fust tier of English local government), thus only holding powers at the behest of the Westminster Parliament. Tony Blair's comparison attracted attention because of its expected remoteness from what the likely political reality would be, and it was a blunder in the Scottish context because it flatly contradicted the substantive appeal of devolution (that is, of real substantive legislative power) to many Scots, in asserting the Westminster Parliament's retention of formal sovereignty. 
3-4- A fourth manifestation, for brief consideration before I return to the European Communities Act 197 and sovereignty in relation to the EU, is the European Union Referendum Act 015, providing for the holding of a referendum on whether the UK should remain a member of the EU. This was also an exercise of formal legislative sovereignty with far-reaching substantive effects of which we are now all too aware - a highly questionable open-ended abrogation of substantive parliamentary responsibility and the invocation of direct democracy on a technical and multi-faceted issue or, rather, a multiplicity of such issues.

Behind the unease accompanying these four profound exercises of Parliament's formal legal sovereignty are substantive conceptions of the necessarily, or unduly, limited actuality of the scope of its sovereignty in consequence. Various commentators have therefore identified divergence in the reality of Parliament's sovereignty from its accepted or traditional legal form ${ }^{3} 5$, have concluded that it still remains $<<$ formally intact as a matter of law $>>$ but questionable in $<<$ practical realism $>>36$, or have sort to take full account of the reality of the increasingly complex substantive political and legal constraints upon $\mathrm{it}^{3} 7$.

3.s. Two further doctrinal conceptions of Parliament's sovereignty are distinguishable and are worth mentioning because of the tension between form and substance that has been manifest in their invocation or elaboration.

The one conception has been of a modified sovereignty of Parliament, exercising plenary power inclusive of the power to make laws binding itself in respect of its own procedure and legislative forms (for example, precluding an Act of Parliament's implied repeal by a later enactment). It is of a Parliament empowered to make binding laws <<that do not in any way diminish parliament's substantive power $>>$ but precisely so as $<<$ to protect itself from its own inadvertence $>$ and thus keep the substantive law-making power unaffected ${ }^{38}$. Formal restrictions on Parliament's sovereignty have been advocated to secure its substance.

The other doctrinal conception has been of a formal, capacious and legally fictitious conception centred on the presumed intention ofthe presumed-to-he-all-powerful Parliament, an intention inferred also from Parliament's inaction. It has been invoked in the context of English administrative law to provide constitutional justification for what developed beyond Parliament, in particular to provide justification for the grounds for the judicial review of administrative action, which developed through the exercise of what has traditionally been viewed as the English courts' original jurisdiction to supervise administrative and other governing authorities. Heavy reliance has been placed on the argument that $<<$ what an all powerful Parliament does not prohibit, it must authorise either expressly or impliedly $>{ }^{3}$ 9. Thus, when Parliament has not legislated to alter the general effect of a court decision or decisions in the judicial review of administrative action, it has been taken to authorise, specifically or in general, the accompanying development of the grounds of review. The English courts, then, in finding administrative action ultra vires, i.e. beyond the administrative body's powers, on the basis of a ground of review, are taken to have been acting in accordance 
with the presumed intention of the sovereign Parliament that the courts develop that ground in particular and/or the rule of law more generally $4^{\circ}$. Constitutional justiftcation though recourse to the presumed intention ofthe presumed-to-he-all-powerful Parliament in the doctrine of ultra vires has been expressly promoted by its leading early advocate as a necessary ftg leaf, which does not deceive anyone, to avoid or conceal conflict between the role of the courts and that of Parliament4'. The ftgleaf is reason to reflect on the steadfastness of that love for legal forms and acquiescence in legal ftctions of the English legal spirit of which Dicey spoke in his comparative constitutionallectures $4 Z_{\text {_ }}$ This time it has been exemplifted in a presumed, capacious and legally ftctitious intention of a presumedto-he-all-powerful sovereign Parliament. Not surprisingly, this invocation and elaboration of Parliament's sovereignty, in developing the doctrine of ultra vires so as to justify judge-made English administrative law, has attracted severe criticism for its excessive legal formalism $4^{3}$.

\section{N. The European CommunitiesAct 1974}

A further, fundamental, manifestation of the exercise of the Westminster Parliament's formal legal sovereignty and of profound implications for its substance was the effective transfer of certain central and substantive legislative and adjudicative powers to what became the institutions of the $\mathrm{Eu}$ ropean Union, in domestic law through the European Communities Act 197 .

Before Britain joined the European Communities, the doctrine of the suprem- acy of Community law was well established in the case law of the ECJ. Re-reading, with Brexit in mind, the judicial dicta from the leading ECJ cases on the supremacy of Community law, I am struck more than I previously was by their assertiveness and uncompromising lack of qualiftcation.

From the ECJ's judgment in 1964 in Costa v. ENEL44 we have the following:

The integration into the laws of each Member State of provisions which derive from the Community, and more generally the terms and the spirit of the Treaty, make it impossible for the States, as a corollary, to accord precedence to a unilateral and subsequent measure over a legal system accepted by them on a basis of reciprocity. Such a measure cannot therefore be inconsistent with that legal system. [...] It follows from all these observations that the law stemming from the Treaty, an independent source of law, could not, because of its special and original nature, be overridden by domestic legal provisions, however framed, without being deprived of its character as Community law and without the legal basis of the Community itself being called into question. The transfer by the States from their domestic legal system to the Community legal system of the rights and obligations arising under the Treaty carries with it a permanent limitation of their sovereign rights, against which a subsequent unilateral act incompatible with the concept of the Community cannot prevail.

From the ECJ's judgment in 1970 in the Intemationale Handelsgesellschaft $\mathrm{mbH}$ case 45 we have further:

Recourse to the legal rules or concepts of nationallaw in order to judge the validity of measures adopted by the institutions of the Community would have an adverse effect on the uniformity and efficacy of Community law. The validity of such measures can only be judged in the light of Community law. In fact, the law stemming from the Treaty, an independence source of law, cannot because of its very nature be overridden by rules of national law, however framed, without being deprived of its character as Community law 
and without the legal basis of the Community itself being called into question. Therefore the validity of a Community measure or its effect within a Member State cannot be affected by allegations that it runs counter to either fundamental rights as formulated by the constitution of that State or principles of a national constitutional structure.

Unmistakeable in these passages are the strong assertions about what was possible, or rather <<impossible for the States, as a corollary $>>$ of acceptance and reciprocity, assumptions, indeed question-begging $4^{6}$, about the <<original nature>> of Community law, its $<<$ very nature $>>$, thus with a given or pre-determined character, $<<$ the concept of the Community >>, its $<<$ legal basis $>>$, and the priority accorded to the <<uniformity and efftcacy of Community law > as essential for the working of the common market. In short, the lack of judicial restraint, explanation and any conceivable condition, qualiftcation or alternative is striking, as is the patency of assertion of Community law's supremacy. It was an assertion of legal supremacy not tempered by the geographical remoteness of the areas over which supremacy was being claimed and exercised, as had been the case in the much earlier, British imperial, form of transnational, indeed transcontinental, constitutionalism47.

Britain joined, nonetheless, the European Communities, and the Westminster Parliament has provided for the implementation of the relevant Treaties (now the EU Treaties) in the European Communities Act 197 - Sub-section (4) of the Act has required that <<any enactment passed or to be passed ... shall be construed and have effect subject to the foregoing provisions $>>$. As those familiar with the development of EU law in the UK will know, the domestic crunch came in the Factortame litigation. On a preliminary reference to the ECJ from the House of Lords in the ftrst Factortame case $4^{8}$, the ECJ re-asserted that requirements to secure the full force and effectiveness of Community law were its <<very essence $>>$ and ruled that, if the sole obstacle to granting effective interim relief for the protection of rights under Community law was a rule of national law, that rule of nationallaw must be set aside49. On the facts, the disapplication of provisions of the Merchant Shipping Act 1988 was thus required under Community law. In the second Factortame case, the House of Lords (as it then was) acted accordingly, and in very few words. Of the Law Lords, only Lord Bridge spoke of implications for Parliament's sovereignty. In answer to comments in the press that this was a < <novel and dangerous invasion by a Community institution of the sovereignty >> of the UK Parliament, Lord Bridge asserted that those comments were $<<$ based on a misconception $>>5^{\circ}$. On the basis that Parliament, in passing the European Communities Act 197 , had accepted whatever limitation of its sovereignty was involved, he concluded that $<<$ there is nothing in any way novel in according supremacy to rules of Community law in those areas to which they apply $>5$. $^{1}$ What was undoubtedly novel, however, was abandonment, in context, of the doctrine of implied repeal: the later Merchant Shipping Act 1988 was not taken to have repealed by implication the earlier European Communities Act 197 - Lord Bridge said nothing at all about implied repeal.

Shortly thereafter, in contributing to the Liber Amicorum for Lord Slynn (former Attorney General of the ECJ), I depicted the second Factortame case as an illustration of 
English judicial minimalism - < <the economy of the common law $>>$ sz. Looking back after the Brexit Referendum and with the benefit of hindsight, I am less sanguine than I was, necessitating reconsideration and, I would suggest, a change of emphasis.

The second Factortame case has been relevant to Brexit, I would argue, alongside much else besides, both by accident and by design. Relevant by accident was also, for example, the expectation that the referendum called would never actually be held, because pollsters were consistently predicting a hung Parliament and the resistance of a coalition government. Relevant by design was also, for example, the Remain campaign's deciding to avoid sustained emphasis on the various advantages of EU membership, on the basis that their own early referendum polling suggested that the economic impact or risk arguments would attract more support. The many causes of Brexit are undeniable, but the decision in the second Factortame case, to which Suella Fernandes MP expressly referred in the Brexit debate in Queens' College, was presented as minimalist or economical and may have seemed so, at least at the time, but was also insufficiently explained and justified. In response to the ECJ's renewed assertion of the supremacy of Community law, provisions of the Merchant Shipping Act 1988 were disapplied, directly negating the formal sovereignty of the Westminster Parliament as exercised in the most recent applicable parliamentary enactment - a direct negation, both by the ECJ and by the highest British court, of one of the residual legal forms and fictions of the English legal spirit described by Dicey (although alongside various substantive conceptions of Parliament's sovereignty, as argued above).
The doctrine of the implied repeal of an inconsistent earlier Act of Parliament by a later one to the extent of the inconsistency was abandoned in relation to the European Communities Act 197 , but without any recognition or explanation.

The abandonment of the doctrine of implied repeal in the second Factortame case not only negated the formal conception of Parliament's sovereignty as traditionally understood. It also confirmed in effect a significant political obstacle to the exercise of Parliament's substantive sovereign power to respond pragmatically to new situations as they arise in areas subject to Community law. The possibility of express repeal of the European Communities Act 197 surely remained $5^{3}$, but short of such a drastic measure - short of that express and substantive political exercise of Parliament's sovereignty- the thorough implementation of EU law through the 197 Act and the working of the ECJ's doctrines of direct effect and supremacy of Community law secured and maintained the day-to-day application of large swathes of EU law in the UK. In the second Factortame case, the effect of the House of Lord's decision on both the formal legal and substantive political conceptions of Parliament's sovereignty required considerably more judicial attention than it received. The decision amounted to little more than <<general obfuscation>>, one of the forms of the common law's economy listed in The English Historical Constitution54. It was, however, an extreme manifestation that has now proved to be unstable - a false economy - through the starkness of the failure to explain or even acknowledge pressing issues at stake and thus not clearly or specifically to address them. 
In short, the ECJ's unrestrained and unqualified assertion of the supremacy of Community law, and the British courts very apparent but poorly explained and justified, indeed barely mentioned, acceptance of it, constituted a soft target for euro-sceptics. It afforded little with which to address even intellectual or academic legal euro-scepticism, which, through various twists and turns, contributed to the outcome of the Brexit referendum. Pressing issues of Parliament's sovereignty were inadequately recognised and explained, and left unresolved, serving as sources of instability.

\section{Concluding Remarks}

Let me conclude by briefly considering doctrinal and constitutional options and implications for the UK and by raising questions for the EU.

In responding to the UK's formal legal and substantive political conceptions of Parliament's sovereignty, there would seem to be three general options, the relative merits and demerits of which warrant a few words now but also further thought, investigation and elaboration well beyond the scope of this lecture.

The first option is doctrinal traditionalism. It is the option of remaining true to Diceyan orthodoxy by keeping the formal legal conception of Parliament's sovereignty for the courtroom and out of the political arena, where the substantive conception is appropriate. Whether or how the European Union was an enhancement or diminution of Parliament's substantive political sovereignty should thus have been central in considering Brexit. For various reasons, taking this option is not as easy as it might seem. Formal legal conceptions slip easily into the English political arena, historically as Dicey observed55, and as debating Brexit has shown. Further, are we in Britain not yet exhausted of all these constitutionallegal forms and fictions, their unreality, and in this instance, the varying tension of a formal legal conception of Parliament's sovereignty with a substantive political conception? And Dicey's The Law of the Constitution may have served as the English substitute for a written constitution in the past $5^{6}$, but no longer does so, even or especially on the issue of sovereignty57.

A second option is renewed doctrinal and judicial clarification, adaptation and justification of form, substance and their interaction in the exercise of sovereignty, so as to reduce the tension or remove the dichotomy between formal legal and substantive political conceptions $5^{8}$. But how exactly to unravel and retie the legal political sovereignty knot remains unclear, as does how to do so without judicial endorsement of constraints upon Parliament's sovereignty that might well still be seen, in traditional terms, to jeopardise the independence of the courts and to encroach unacceptably upon that sovereignty. The legitimacy of the doctrinal and judicial reformation might well remain elusive or questionable.

A third option, for the sake of legitimacy, is juridicalisation or juridification (to use the key word in the ReConFort project) in a fully codified constitution, setting out a separation of powers, the powers and responsibilities of the courts and of Parliament, provisions for constitutional amendment, and so forth. Despite Jeremy Bentham's early, strong and prominent advocacy of codification of the whole of 
the English common law, Britain has shied away from it, especially from codification of its historical or unwritten constitution59. Further, taking on the huge and daunting political and legal task of introducing a codified constitution remains remote amidst all the governmental political and legal work that will accompany Brexit.

On constitutional implications for the EU, I can only express doubts and ask questions, because my area of expertise is not EU law. Was there sufficient pragmatic self-restraint in the unqualified assertion and development of the doctrine of the supremacy of Community law? Was enough done by the ECJ to refine, explain and justify the doctrine? Finally, was the seemingly implicit positivist methodology of a hierarchy of legal sources with a change of the Grundnmm on offer in the legal orders of member states up to the task of justification and securing legitimacy?

On the Way to furidiftcation by Constitution is the title of your conference. I would agree what we are only on the way, because much more is needed by way of clarification and principled justification, especially on issues of sovereignty, for the constitutional legitimacy of political orders to be securely established, both in Britain and seemingly in the European Union. Much more is needed, at least on the one hand, if one assumes, as I have now done, that "juridification" involves substantive justification for the sake of legitimacy. If, on the other hand, "juridification" is meant as a narrow technical pursuit of legal clarity in a political order's sources of law, such juridification seems insufficient per se to establish legitimacy. What is still needed, in the English context at least, is both clarification and further principled justification on issues of sovereignty, especially if populist or nationalist challenges, advanced under the banner of sovereignty, are to be met effectively. This basic need makes your project, of which this conference is a product, all the more pertinent and important.
* Honorary Lecture, Mid-term ReConFort Conference, On the Way to Juridification by Constitution, I September oi6, Carl Friedrich von Siemens Stiftung, Munich.

- The exercise of sovereignty was the enactment of the European Union Referendum Act OI5 under which the Brexit referendum (i.e. the United Kingdom European Union membership referendum, oi6) was held.

See J.W.F Allison, The English Historical Constitution, Continuity.
Change and European Effects, Cambridge, CUP, oo7, pp. no-n9.

3 Case C- I3/89, $R$ v. Secretary of Statefor Transport. exparte Factortame Ltd. (No. ) [I99I] I AC 6o3, [I99ol ECRł 433.

4 A.V. Dicey, The Law of the Constitution, in The Oxford Edition of Dicey, ed. by J.W.F. Allison, Oxford, OUP, oi3, vol. I.

5 See P. Craig, Formal and Substantive Conceptions of the Rule of Law, An Analytical Framework, in «Public Law», Autumn, I997• pp. $467 \mathrm{ff}$.
6 Dicey, The Law of the Constitution cit., pp. 4I ff.

7 [vi,p. 41.

8 !vi,pp. 39 ff.

9 A.V. Dicey, Comparative Constitutionalism, in The Oxford Edition of Dicey, ed. by J.W.F. Allison, Oxford, OUP, oi3, vol. II.

w !vi, pp. 70, 9 .

n !vi,pp. I79• I78.

q vi, PP. I8 . I8I f.

13 Dicey's comparative constitutional lecture on representative government also highlights a problem for his account of par- 
liamentary sovereignty's two senses. By way of an analogy between representation in Parliament and agency in private law and on the basis that there can be no universal agent in private law, he concluded that the «authority vested in Parliament is rather indefmite than absolute». i.e. subject to a limit inherent in its popular representative character (ivi. pp. 18 f.). The apparent problem for Dicey of tension between parliamentary sovereignty and popular sovereignty was aggravated institutionally by Dicey's being the referendum's f:trst English advocate (ivi, pp. $70 \mathrm{ff}$.; see also ivi, Editor's Introduction, pp. XXX f.). The tension is now manifest in the outcome of the Brexit referendum, in which a substantial majority of MPs favoured to remain in the EU, and a clear majority of the electorate voted to leave. In his comparative constitutional lectures, Dicey's recognition ofthat inherent limit to Parliament's sovereignty was counterbalanced by his emphasis on the great authority that Parliament derived from the parliamentary character of its executive (ivi, Editor's Introduction, pp. XXXII ff.).

14 Ivi,pp.I75ff.

'5 See, e.g., Dicey, The Law of the Constitution cit., pp. 95, n3 ff.,

16 Ivi, pp. US, II9.

${ }^{1} 7$ Ivi, pp. 7 ff., 8.

18 Ivi, pp. $44 \mathrm{ff}$.

'9 J.L. De Lolme, The Constitution of England, Dublin, W. Wilson, '775. p. 38; H. Cox, The Institutions of the English Government, London, H. Sweet, I863, pp. 8-10.

o E. Coke, The Fourth Part of the Institutes of the Laws of England, London, W. Clarke, I817'7, 36.

' W. Blackstone, Commentaries on the Laws of England, Oxford, Clarendon Press, vol. I, 1765, p. 156. W.E. Hearn, The Government of England, Its Structure and Its Development, London, Longmans, 1867 , p. 50.
3 Dicey, The Law of the Constitution cit., p. 5 .

4 British Coal Corporation v. $R$ [1935] AC 5oo, 5 o (author's emphasis).

5 Blackburn v. Attorney General [I97I]I WLR 1037, 1040.

${ }^{6}$ D. Lino, Albert Venn Dicey and the Constitutional Theory of Empire, in «Oxford Journal of Legal Studies», vol. XXXVI, n. 4, 016, pp. $75^{\prime}$ ff., p. 780.

7 !vi,p. 777.

8 On many uses of Henry VIII clauses and the various arguments used to justify them, see N.W. Barber andA.L. Young, The Rise of Prospective Henry VIII Clauses and Their Implications for Sovereignty, in «Public Law», Spring, oo3, pp. $\mathbf{n} \mathrm{ff}$.

9 Lord Judge, Henry VIII Clauses, in Lord Judge, The Safest Shield, Lectures, Speeches and Essays, Oxford, Hart, 015, pp. 99-106.

30 Ivi, p. 105.

31 Ivi, p. 106.

3 See now the European Union (Withdrawal) Bill 017-019 (HC Bills).

33 Sub-section 8 (7).

$3_{4}^{3}$ J. Penman, Real Power win Stay with MPs in England, Blair teUs Scotland, in «The Scotsman», 4 April1997, p. 1. See I.Mclean, The National Question, in A. Seldon (ed.by), Biair'sBritain, '997-ooz, PP. 487-508, 49 .

35 See, e.g., A.W. Bradley, K.D. Ewing and C.J.S. Knight, Constitutional and Administrative Law, 16 edn., Harlow, Pearson, 015, pp. 7 ff. See also A.W. Bradley, The Sovereignty of Parliament Form or Substance?, in J. Jowell and D. Oliver (ed. by), The Changing Constitution, Oxford, OUP, on ${ }^{7}$, pp. 3s-69.

36 C. Turpin and A. Tomkins, British Government and the Constitution, Text and Materials, Cambridge, CUP, on ${ }^{7}$, p. 95.

$3_{7}$ See, e.g. M. Elliott, Legislative Supremacy in a Multidimensional Constitution, in M. Elliott and D. Feldman (ed. by), The Cambridge Companion to Public Law, Cambridge, CUP, pp. 73-
95; M. Elliott, The Principle of Parliamentary Sovereignty in Legal, Constitutional, and Political Perspective, in J. Jowell, D. Oliver and C. O'Cinneide (ed. by), The Changing Constitution, Oxford, OUP, o15 ${ }^{8}$, pp. 38-66.

38 J. Goldsworthy, Parliamentary Sovereignt $Y^{\prime}$ Contemporary Debates, Cambridge, CUP, 010, pp. oo, 18 . See also J. Goldsworthy, The Sovereignty of Parliament, History and Philosophy, Oxford, OUP, 1999• pp. 14-I6.

$3_{9}$ C. Forsyth, Of Fig Leaves and Fai'Y Tales, The Ultra Vires Doctrine, the Sovereignty of Parliament and judicial Review, in «Cambridge Law Journal», vol. LV, 1996, n. 1, pp. 1 ff., I33.

4o See M. Elliott, The Uitra Vires Doctrine in a Constitutional Setting, Stin the Central Principle of Administrative Law, in «Cambridge Law Journal», vol. LVIII, '999. n. 1, pp. ' $9 \mathrm{ff}$.

4' Forsyth, Fig Leaves and Fai'Y Tales Cit., pp. I36-I37.

4 Dicey, Comparative Constitutionalism cit.,pp. 70, '78-,8 .

43 See, e.g., P. Craig, Uitra Vires and the Foundations of judicial Review, in «Cambridge Law Journal», vol. LVII, 1998, n. 1, 63 ff.; T.R.S. Allan, The Constitutional Foundations of judicial Review, Conceptual Conundrum or Interpretative Inqui' $Y$ ?, in «Cambridge Law Journal», vol. LXI, oo . n. 1, $87 \mathrm{ff}$.

44 Case 6/64, Costa v. ENEL [1964] ECR 585, 593-594.

45 Case $\mathrm{n} / 70$, Internationaie HandelsgeseUschaft $m b H$ v. Einfuhrund VorratssteUe fur Getreide und Futtermittel [197ol ECR n s. n34.

46 See the telling criticism of Pavlos Eleftheriadis from the 199 os, which now seems portentous, has been relied on here and deserves renewed attention, Begging the Constitutional Question, in «Journal of Common Market Studies», vol. XXXVI, 1998, n. . pp. 55 ff. See also P. Eleftheriadis, Aspects of European Constitutionalism, in <<European Law Review〉>, vol. 
XXI, 1996,n. 1,pp. $3 \mathrm{ff}$

47 See Dylan, Dicey and the Constitutional Theory of Empire cit,, pp. 775 ff

$48 R$ v. Secretary of Statefor Transport, ex parte Factortame Ltd. [199ol $\mathrm{AC} 85$.

49 Case C- $13 / 89, \quad R$ v. Secretary of State for Transport, ex parte Factortame Ltd. (No. ) [199']' AC 6o3, 644-645, [ o], [ 4]; [199ol ECR+ 433, [ o], [ 4]. On «the very essence of Community law» and its implications, the ECJ was following Case 106/77, Amministrazione delle Finanze de1 1 o Stato v. Simmenthai S.p.A. [1978] ECR 6 9. 644. [ ].

so $R$ v. Secretary of Statefor Transport, ex parte Factortame Ltd. (No. ) ['99'l'AC 6o3, p. 658GH.

$5^{1}$ Ivi, p. 659AB.

s J.W.F. Allison, Parliamentary Sovereignty, Europe and the Economy of the Common Law, in M. Andenas and D. Fairgrieve (ed. by), Judicial Review in International Perspective, The Hague, Kluver, ooo, vol. II, pp. 177-194; Allison, English Historical Constitution cit., ch. 5 .

53 See Lord Denning's obiter dictum in Macarthys v. Smith [1979] 3 All ER 35. 39CD.

54 On this form of judicial economy and other forms available in the English common law, see Allison, English Historical Constitution cit., PP.' 5f, ' 6.

55 Dicey, Comparative Constitutionalism cit.,pp., $\mathrm{S}, \mathrm{f}$

56 See Allison, Editor's Introduction, in Dicey, The Law of the Constitution cit., pp. xrvf

57 According to Lord Steyn in Jackson v.AttomeyGenera[ [ oo6]I AC 6 . [10 ], «The classic account given by Dicey of the doctrine of the supremacy of Parliament, pure and absolute as it was, can now be seen to be out of place in the modern United Kingdom. Nevertheless, the supremacy of Parliament is still the general principle of our constitution».

$5^{8}$ See, e.g., the attempts of Bradley, Sovereignty of Parliament cit.; Elliott, Principle of Parliamentary
Sovereignty cit.

59 Allison, Editor's Introduction, in Dicey, Comparative Constitutionalism cit., pp. XLII $\mathrm{f}$ 
